\title{
Anti-phage serum antibody responses and the outcome of phage therapy
}

\author{
M. Łusiak-Szelachowska ${ }^{1}$ R. Międzybrodzki ${ }^{1,2,3} \cdot$ W. Fortuna ${ }^{1,2,4} \cdot$ J. Borysowski ${ }^{3} \cdot$ Andrzej Górski $^{1,2,5}$ (i)
}

Received: 3 August 2020 / Accepted: 22 October 2020 / Published online: 30 October 2020

(C) The Author(s) 2020

\begin{abstract}
We examined the appearance of serum anti-phage antibodies in 25 patients with chronic sinusitis treated with phage therapy (PT). Approximately $30 \%$ of patients with weak antibody responses responded positively to PT, which was similar to the results of treatment achieved in a group of patients with high antibody production. In addition, there was no correlation between antibody level and the outcome of PT. These data, derived from a homogenous group of patients, confirm our earlier findings suggesting that the prognostic significance of serum anti-phage antibodies for the outcome of PT should be determined by relevant clinical trials.
\end{abstract}

\section{Introduction}

The growing menace of antibiotic resistance has greatly revived interest in phage therapy (PT). In the past few years, a number of reports have been published strongly suggesting that the PT-alone or in association with antibiotics - may be an efficient means of combating multidrug-resistant bacteria. Some authors believe that antibiotic marketplace is broken and that the therapy with bacterial viruses has the potential to be used in the treatment of infectious diseases either alone or as adjuvants to existing therapies (Safir et al. 2020). A number of clinical trials are currently underway which suggests that the real value of PT should eventually be determined

Andrzej Górski

andrzej.gorski@hirszfeld.pl

1 Bacteriophage Laboratory, Hirszfeld Institute of Immunology and Experimental Therapy, Polish Academy of Sciences (HIIET PAS), Wrocław, Poland

2 Phage Therapy Unit, Hirszfeld Institute of Immunology and Experimental Therapy, Polish Academy of Sciences (HIIET PAS), Wrocław, Poland

3 Department of Clinical Immunology, Transplantation Institute, Medical University of Warsaw, Warsaw, Poland

4 Department of Neurosurgery, Wrocław Medical University, Wrocław, Poland

5 Infant Jesus Hospital, Medical University of Warsaw, Warsaw, Poland according to currently required standards of evidence-based medicine.

Phages - as other viruses - may interact with the immune system. Such interactions can lead to anti-phage antibody responses as well as cause immunomodulating effects. In the past years, phage-mediated immunomodulation has received increasing attention. Phage-dependent immunomodulating effects may have therapeutic potential in disorders of the immune system and alleviation of allograft reactivity as well as treatment of some non-bacterial infections (Górski et al. 2019a). Our studies have supplied some data on anti-phage humoral responses of mice receiving phages as well as phage proteins using different routes of phage administration and duration of phage treatment (Dabrowska 2019). Furthermore, we studied anti-phage antibody formation in patients receiving PT (Łusiak-Szelachowska et al. 2014). The results of those studies suggest that humoral responses elicited by PT may depend on route of administration, phage type, duration of the therapy, and patient's immunocompetence. Our initial observations also suggest that there is no apparent association of intensity of humoral anti-phage responses and therapy outcome (Górski et al. 2019b). This observation is somewhat unexpected, as it could be anticipated that such phage neutralizing antibodies would compromise the beneficial effects of phages in patients receiving PT. Evidently, the relationship of anti-phage antibodies and the success of therapy is of obvious practical significance for further advancement of PT, especially planning of decisive clinical trials. Interestingly, available reports of recent clinical trials completed so far do not provide any relevant information so it is 
impossible to determine how anti-phage antibodies could have contributed to trial outcome (Ujmajuridze et al. 2018; Jault et al. 2019; Ooi et al. 2019). In this report, we confirm and extend our earlier preliminary data (Łusiak-Szelachowska et al. 2017), but currently derived from a homogenous group of patients (one clinical model) suggesting that the appearance of serum anti-phage antibodies does not exclude positive outcome for PT.

\section{Materials and methods}

\section{Patients}

Twenty-five patients with chronic rhinosinusitis undergoing PT at our Phage Therapy Unit (PTU) under the therapeutic protocol "Experimental phage therapy of drug-resistant bacterial infections, including MRSA infections" (Międzybrodzki et al. 2012) were included. Patients used phage preparations locally $(n=4)$ or locally and orally $(n=21)$. Topical application of phages was accomplished by sinus irrigation $(2 \times 15$ $\mathrm{mL}$ of phage) or nasal spraying. Topical and oral application was accomplished by nasal drops $(2 \times 4 \mathrm{~mL}$ of phage $)$ and orally ( $2 \times 6 \mathrm{~mL}$ of phage). Before oral phage administration, $10 \mathrm{~mL}$ of dihydroxyaluminum sodium carbonate $(68 \mathrm{mg} / \mathrm{mL})$ was applied orally. Sera were obtained from patients between
2010 and 2019. Sera of voluntary blood donors were obtained from the Blood Transfusion Center in Wrocław, Poland. All subjects gave written informed consent and the study was approved by the Bioethics Committee at Wrocław Medical University (Poland). The blood was centrifuged at $1500 \times g$ for $10 \mathrm{~min}$ and sera were stored at $-70{ }^{\circ} \mathrm{C}$. Blood was collected before, during, and after PT. The neutralization test of phages by sera was performed immediately after obtaining sera. Sera were investigated during PT from day 14 to day 63. The highest $K$ rate during PT was taken to analysis.

\section{Bacteriophage preparations}

Patients used monovalent lysates of Staphylococcus aureus, Pseudomonas aeruginosa, Klebsiella pneumoniae or Escherichia coli phages (22 patients), S. aureus MS-1 phage cocktail (1 patient), and purified $S$. aureus OPMS-1 phage cocktail (1 patient) or purified $S$. aureus OPMS-1 top phage cocktail (1 patient) based on phage typing (Table 1; Table 2). Patients applied mainly $S$. aureus phage preparations (23 patients). S. aureus phage cocktails MS-1, OPMS-1, and OPMS1 top are composed of three $S$. aureus phages - 676/Z, A5/80, P4/6409. Purified phage cocktail OPMS-1 contained phages suspended in phosphate-buffered saline (PBS) with addition of saccharose (stability of storage conditions). Purified phage cocktail OPMS-1 top was deprived of saccharose. Phage

Table 1 Patients with chronic rhinosinusitis with positive responses to PT

\begin{tabular}{|c|c|c|c|c|c|c|}
\hline Patient & $\begin{array}{l}\text { Phage preparation } \\
\text { used in PT }\end{array}$ & $\begin{array}{l}\text { Route of phage } \\
\text { administration }\end{array}$ & $\begin{array}{l}\text { Phage inactivation } \\
(K) \text { before } \mathrm{PT}\end{array}$ & $\begin{array}{l}\text { Phage inactivation } \\
(K) \text { during } \mathrm{PT}^{\mathrm{a}}\end{array}$ & $\begin{array}{l}\text { Day of PT on } \\
\text { which } K \text { was marked }\end{array}$ & $\begin{array}{l}\text { Clinical outcome } \\
\text { of PT }(\mathrm{A}-\mathrm{C})^{\mathrm{b}}\end{array}$ \\
\hline 1 & Staph OPMS-1 & Locally & 0.74 & 28.28 & 62 & $\mathrm{C}$ \\
\hline 2 & $\begin{array}{l}\text { Staph A5/80 } \\
\text { Since 14th day of PT } \\
\quad \text { Staph } 676 / T\end{array}$ & Locally & $\begin{array}{l}0.06 \\
0.85\end{array}$ & $\begin{array}{l}0.16 \\
12.06\end{array}$ & $\begin{array}{l}14 \\
55\end{array}$ & A \\
\hline 3 & Pseud Psmw31 & Locally and orally & 0.00 & 0.002 & 14 & $\mathrm{~B}$ \\
\hline 4 & Staph OPMS-1 top & Locally and orally & 0.25 & 4.25 & 15 & $\mathrm{C}$ \\
\hline 5 & Staph 676/T & Locally and orally & 0.36 & 48.21 & 49 & A \\
\hline 6 & Staph 676/Z & Locally and orally & 0.03 & 1.21 & 48 & B \\
\hline 7 & $\begin{array}{l}\text { Klebs K1 16/30 } \\
\text { Coli } 126 / 2031\end{array}$ & Locally and orally & $\begin{array}{l}0.005 \\
0.01\end{array}$ & $\begin{array}{l}0.02 \\
0.11\end{array}$ & 31 & $\mathrm{C}$ \\
\hline 8 & Staph A5/L & Locally and orally & $\begin{array}{l}0.03 \\
\text { Mean } K \pm S D 0.23 \pm 0.32\end{array}$ & $\begin{array}{l}0.72 \\
\text { Mean } K \pm S D^{*} 9.50 \pm 16.28 \\
\quad(\text { Wilcoxon test, } p=0.005)\end{array}$ & $\begin{array}{l}14 \\
14-62\end{array}$ & $\mathrm{C}$ \\
\hline
\end{tabular}

$K$ rate of phage inactivation, $P T$ phage therapy, $S D$ standard deviation

$K<5$, low neutralization of phages

$K=5-18$, medium neutralization of phages

$K>18$, high neutralization of phages

${ }^{\text {a }}$ Maximum $K$ achieved during PT

${ }^{\mathrm{b}}$ Results A-C positive responses to PT

* Significantly associated with the increase in the $K$ rate during PT compared to the $K$ rate before PT (Wilcoxon test; $p=0.005$ ). There was no statistically significant difference (Mann-Whitney $U$ test; $p=0.65$ ) in the $K$ rate during PT between positive responses to PT (Table 1) and inadequate responses to PT (Table 2) 
Table 2 Patients with chronic rhinosinusitis with inadequate responses to PT

\begin{tabular}{|c|c|c|c|c|c|c|}
\hline Patient & $\begin{array}{l}\text { Phage preparation } \\
\text { used in PT }\end{array}$ & $\begin{array}{l}\text { Route of phage } \\
\text { administration }\end{array}$ & $\begin{array}{l}\text { Phage inactivation } \\
(K) \text { before PT }\end{array}$ & $\begin{array}{l}\text { Phage inactivation } \\
(K) \text { during } \mathrm{PT}^{\mathrm{a}}\end{array}$ & $\begin{array}{l}\text { Day of PT on } \\
\text { which } K \text { was marked }\end{array}$ & $\begin{array}{l}\text { Clinical outcome } \\
\text { of PT (D-G) }{ }^{\mathrm{b}}\end{array}$ \\
\hline 1 & Staph 676/Z & Locally & 0.37 & 24 & 51 & $\mathrm{E}$ \\
\hline 2 & Staph $\phi 200$ & Locally & 0.03 & 0.12 & 14 & $\mathrm{~F}$ \\
\hline 3 & Staph MS-1 & Locally and orally & 0.07 & 0.26 & 31 & $\mathrm{~F}$ \\
\hline 4 & Staph P4 & Locally and orally & 0.21 & 0.24 & 21 & $\mathrm{E}$ \\
\hline 5 & Staph $\phi 200$ & Locally and orally & 0.33 & 0.21 & 26 & $\mathrm{E}$ \\
\hline 6 & Staph A5/L & Locally and orally & 0.11 & 75.12 & 56 & $\mathrm{E}$ \\
\hline 7 & Staph 1 N/80 & Locally and orally & 0.02 & 1.42 & 17 & $\mathrm{E}$ \\
\hline 8 & Staph A5/L & Locally and orally & 0.02 & 68.94 & 30 & $\mathrm{E}$ \\
\hline 9 & Staph 676/F & Locally and orally & 0.00 & 0.9 & 32 & $\mathrm{~F}$ \\
\hline 10 & Staph 676/F & Locally and orally & 0.02 & 0.14 & 17 & $\mathrm{~F}$ \\
\hline 11 & Staph 676/F & Locally and orally & 0.03 & 0.07 & 63 & $\mathrm{~F}$ \\
\hline 12 & $\begin{array}{l}\text { Staph 676/T } \\
\text { Coli 76/850 }\end{array}$ & Locally and orally & $\begin{array}{l}0.35 \\
0.00\end{array}$ & $\begin{array}{l}0.42 \\
0.007\end{array}$ & 14 & G \\
\hline 13 & Staph 676/T & Locally and orally & 0.00 & 22.53 & 26 & G \\
\hline 14 & Staph 1 N/80 & Locally and orally & 0.34 & 0.53 & 47 & $\mathrm{~F}$ \\
\hline 15 & Staph 1 N/80 & Locally and orally & 0.19 & 0.67 & 18 & $\mathrm{~F}$ \\
\hline 16 & Staph 676/T & Locally and orally & 0.52 & 0.92 & 18 & $\mathrm{~F}$ \\
\hline 17 & Staph $\phi 200$ & Locally and orally & $\begin{array}{l}0.00 \\
\text { Mean } K \pm S D 0.14 \pm 0.17\end{array}$ & $\begin{array}{l}0.15 \\
\text { Mean } K \pm S D^{*} 10.92 \pm 23.43 \\
\quad(\text { Wilcoxon test, } p=0.0006)\end{array}$ & $\begin{array}{l}14 \\
14-63\end{array}$ & $\mathrm{~F}$ \\
\hline
\end{tabular}

$K$ rate of phage inactivation, $P T$ phage therapy, $S D$ standard deviation

$K<5$, low neutralization of phages

$K=5-18$, medium neutralization of phages

$K>18$, high neutralization of phages

${ }^{a}$ Maximum $K$ achieved during PT

${ }^{\mathrm{b}}$ Results D-G inadequate responses to PT

*Significantly associated with the increase in the $K$ rate during PT compared to the $K$ rate before PT (Wilcoxon test; $p=0.0006$ ). There was no statistically significant difference (Mann-Whitney $U$ test; $p=0.65$ ) in the $K$ rate during PT between positive responses to PT (Table 1) and inadequate responses to PT (Table 2)

preparations were used in the following concentrations: monovalent phage lysate $10^{6}-10^{8}$ plaque forming unit $/ \mathrm{mL}$ (pfu/mL), S. aureus MS-1 phage lysate cocktail $10^{6}-10^{8}$ $\mathrm{pfu} / \mathrm{mL}$, and purified $S$. aureus OPMS-1 and OPMS-1 top phage cocktails $10^{9} \mathrm{pfu} / \mathrm{mL}$.

\section{Phage neutralization test}

Phage neutralization by human sera was performed as described earlier (Łusiak-Szelachowska et al. 2017). Anti-phage activity of sera (AAS) was calculated as phage inactivation ( $K$ rate), where $K$ less than 5 was considered as a low neutralization of phages, $K$ between 5 and 18 as a medium level, and above 18 as a high neutralization of phages. The $K$ rate was estimated using the formula $K=2.3 \times(D / T) \times \log (\mathrm{P} 0 / \mathrm{Pt})$, where $K$ is the rate of phage inactivation, $D$ is the reciprocal of the serum dilution, $T$ is the time in minutes during which the reaction occurred $(30 \mathrm{~min}), \mathrm{P} 0$ is the phage titer at the start of the reaction, and $\mathrm{Pt}$ is the phage titer at time $T$.
Statistical analysis for $K$ rate was performed using the Wilcoxon rank sum test (dependent trials) or Mann-Whitney $U$ test (independent trials). The level of statistical significance $(p)$ was calculated for frequencies of results of PT by the $V$ squared test. $p<0.05$ was considered as significant.

\section{Categories of the outcome of PT}

The outcome of PT was evaluated according to Międzybrodzki et al. (2012).

Categories A-C were considered as positive responses to PT: A-pathogen eradication and/or recovery (eradication confirmed by the results of bacterial cultures; recovery refers to wound healing or complete subsidence of the infection symptoms), B - good clinical result (almost complete subsidence of some infection symptoms, together with a significant improvement of the patient's general condition after completion of PT), C-clinical improvement (discernible reduction in the intensity of some infection symptoms after completion 
Table 3 Outcome of PT depending on $K$ for patients with chronic rhinosinusitis using phages locally or locally and orally

\begin{tabular}{|c|c|c|c|}
\hline Parameters & Before PT & During PT & $p$ (Wilcoxon test) \\
\hline \multicolumn{4}{|c|}{ Outcome of PT for patients using phages locally or locally and orally $n=25$} \\
\hline Mean $K \pm S D^{*}$ & $0.17 \pm 0.23$ & $10.41 \pm 20.84$ & 0.00001 \\
\hline Outcome of PT $(\mathrm{A}-\mathrm{C})^{\mathrm{a}}, n(\%)$ & - & $8(32 \%)$ & - \\
\hline Outcome of PT (D-G),$n(\%)$ & - & $17(68 \%)$ & - \\
\hline \multicolumn{4}{|c|}{ Outcome of PT for patients using phages locally or locally and orally $n=25$ depending on $K$} \\
\hline & $K<5 ; n=18$ & $K=5-18 ; n=1$ & $K>18 ; n=6$ \\
\hline Mean $K \pm S D$ before PT & $0.12 \pm 0.15$ & 0.85 & $0.27 \pm 0.28$ \\
\hline Mean $K \pm S D$ during PT* & $0.59 \pm 0.93$ & 12.06 & $44.51 \pm 23.30$ \\
\hline$p$ (Wilcoxon test) & 0.0003 & - & 0.03 \\
\hline Outcome of PT $(\mathrm{A}-\mathrm{C})^{\mathrm{a}}, n(\%)$ & $5(27.8 \%)^{\#}$ & $\mathrm{n}=1$ & $2(33.3 \%)^{\#}$ \\
\hline Outcome of PT $(\mathrm{D}-\mathrm{G})^{\mathrm{b}}, n(\%)$ & $13(72.2 \%)$ & - & $4(66.7 \%)$ \\
\hline
\end{tabular}

$K$ rate of phage inactivation, $P T$ phage therapy, $S D$ standard deviation

$K<5$, low neutralization of phages

$K=5-18$, medium neutralization of phages

$K>18$, high neutralization of phages

${ }^{\text {a }}$ Results A-C positive responses to PT

${ }^{\mathrm{b}}$ Results D-G inadequate responses to PT

*Significantly associated with the increase in the $K$ rate during PT compared to the $K$ rate before PT (Wilcoxon test; $p<0.05$ )

\# There was no statistically significant difference $(V$-squared test; $p=0.79)$ in the frequencies between positive responses to PT for patients with $K<5$ and $K>18$

of PT to a degree not observed before PT, when no treatment was used).

Categories D-G were considered as inadequate responses to PT: D-questionable clinical improvement (reduction in the intensity of some infection symptoms to a degree that could also be observed before PT), E-transient clinical improvement (reduction in the intensity of some infection symptoms observed only during application of phage preparations and not after termination of $\mathrm{PT}$ ), $\mathrm{F}-\mathrm{no}$ response to treatment (lack of reduction in the intensity of some infection symptoms observed before PT), Gclinical deterioration (exacerbation of symptoms of infection at the end of PT).

\section{Results}

AAS was examined by phage neutralization test in 25 patients with chronic rhinosinusitis who received phages locally $(n=$ $4)$ or locally and orally $(n=21)$ (Table 1 ; Table 2$)$. Twentythree patients used Staphylococcus aureus phages and 3 patients used Pseudomonas aeruginosa, Klebsiella pneumoniae, or Escherichia coli phages. AAS control consisted of 30 sera of healthy individuals. The mean phage inactivation $K$ rate in sera of healthy subjects for $S$. aureus $\phi 200$ phage was $0.17 \pm$ 0.45 . Two groups of patients were distinguished: (1) with a positive responses to PT (categories A-C) $(n=8)$ (Table 1) and (2) inadequate responses to PT (categories (D-G) $(n=17)$ (Table 2). Patients in group 1 prior to PT showed low mean $K$ rate $=0.23 \pm 0.32$ and in group 2 before PT, the mean $K$ rate was also low at $0.14 \pm 0.17$. During PT, the $K$ rate increased significantly (Wilcoxon test, $p<0.05$ ) in group patients 1 and 2 (mean $K$ rate $=9.50 \pm 16.28$ (days 14 to 62 ) vs. mean $K=$ $10.92 \pm 23.43$ (days 14 to 63 ), respectively). When the $K$ rates during therapy between the group of patients with a positive responses to therapy and the group with inadequate responses to therapy were compared, no statistically significant differences were found (Mann-Whitney $U$ test, $p=0.65$ ) suggesting no differences between the $K$ levels in both clinically analyzed groups.

Examination of the $K$ rates in all patients, using phages locally or locally and orally, has revealed low phage neutralization before PT (mean $K=0.17 \pm 0.23$ ) (Table 3 ). The $K$ rate increased significantly (Wilcoxon test, $p<0.05$ ) in patients during PT (mean $K=10.41 \pm 20.84$ ). Then, 6 patients out of $25(24 \%)$ had a high phage inactivation $K$ rate (above 18 ) during PT (days 26 to 62). During PT, patients with $K<5$ $(n=18)$ had a positive result of PT in $27.8 \%$ of cases $(n=$ $5)$, while patients with $K>18(n=6)$ had a positive result of PT in $33.3 \%$ of cases $(n=2)$ suggesting that the level of phage neutralization does not affect the clinical outcome of PT. The differences were not statistically significant between the frequency of cases with positive responses to PT for patients with $K<5$ and $K>18$ ( $V$-squared test; $p=0.79)$. 
Analysis of the AAS level in the group of patients with chronic rhinosinusitis in relation to the results of PT reveals lack of significant correlation between those two parameters.

\section{Discussion}

The data presented in this communication confirms our previous suggestions derived from studies conducted on a heterologous group of 20 patients with soft tissue infections, bone infections, and respiratory infections showing that good therapy outcome may be noted in patient groups with both low and high anti-phage responses $(K<5$ and $K>18)$ (LusiakSzelachowska et al. 2017). We have suggested that local interactions between phages and antibodies capable of penetrating the sites of bacterial infections are more relevant for the outcome of PT than such interactions in the peripheral blood (Górski et al. 2019b). Antibody production to intravenously administered phage has been used in the diagnostics and monitoring in patients with immunodeficiency syndrome (Ochs et al. 1971). Thus, the appearance of anti-phage antibodies in the blood could be a marker of immune recovery during PT and constitute a good prognostic sign, at least in some patients (Górski et al. 2019b).

Evidently, more data is needed to determine the role of anti-phage antibody responses in the success of PT. Importantly, all relevant clinical trials should include that parameter to provide the necessary information.

Authors' contributions Marzanna Łusiak-Szelachowska: conceived the study and analyzed data; Ryszard Międzybrodzki: analyzed data; Wojciech Fortuna and Jan Borysowski: wrote parts of the manuscript; Andrzej Górski: conceived the study and wrote the manuscript. All authors approved the manuscript.

Funding This work was supported by statutory funds of the Hirszfeld Institute of Immunology and Experimental Therapy, Polish Academy of Sciences.

\section{Compliance with ethical standards}

Conflict of interest A. Górski, R. Międzybrodzki, and J. Borysowski are co-inventors of patents owned by the Hirszfeld Institute of Immunology and Experimental Therapy and covering phage preparations. M. ŁusiakSzelachowska and W. Fortuna declare that they have no conflict of interest.

Open Access This article is licensed under a Creative Commons Attribution 4.0 International License, which permits use, sharing, adaptation, distribution and reproduction in any medium or format, as long as you give appropriate credit to the original author(s) and the source, provide a link to the Creative Commons licence, and indicate if changes were made. The images or other third party material in this article are included in the article's Creative Commons licence, unless indicated otherwise in a credit line to the material. If material is not included in the article's
Creative Commons licence and your intended use is not permitted by statutory regulation or exceeds the permitted use, you will need to obtain permission directly from the copyright holder. To view a copy of this licence, visit http://creativecommons.org/licenses/by/4.0/.

\section{References}

Dąbrowska K (2019) Isolation of competitive phage display-modified bacteriophage T4 with affinity chromatography. Methods Mol Biol 1898:81-87. https://doi.org/10.1007/978-1-4939-8940-9_7

Górski A, Bollyky PL, Przybylski M, Borysowski J, Międzybrodzki R, Jończyk-Matysiak E, Weber-Dąbrowska B (2019a) Perspectives of phage therapy in non-bacterial infections. Front Microbiol 9:3306. https://doi.org/10.3389/fmicb.2018.03306

Górski A, Międzybrodzki R, Jończyk-Matysiak E, Borysowski J, Letkiewicz S, Weber-Dabrowska B (2019b) The fall and rise of phage therapy in modern medicine. Expert Opin Biol Ther 19(11): 1115-1117. https://doi.org/10.1080/14712598.2019.1651287

Jault P, Leclerc T, Jennes S, Pirnay JP, Que YA, Resch G, Rousseau AF, Ravat F, Carsin H, Le Floch R, Schaal JV, Soler C, Fevre C, Arnaud I, Bretaudeau L, Gabard J (2019) Efficacy and tolerability of a cocktail of bacteriophages to treat burn wounds infected by Pseudomonas aeruginosa (PhagoBurn): a randomised, controlled, double-blind phase 1/2 trial. Lancet Infect Dis 19(1):35-45. https:// doi.org/10.1016/S1473-3099(18)30482-1

Łusiak-Szelachowska M, Żaczek M, Weber-Dąbrowska B, Międzybrodzki R, Kłak M, Fortuna W, Letkiewicz S, Rogóż P, Szufnarowski K, Jończyk-Matysiak E, Owczarek B, Górski A (2014) Phage neutralization by sera of patients receiving phage therapy. Viral Immunol 27(6):295-304. https://doi.org/10.1089/vim. 2013.0128

Łusiak-Szelachowska M, Żaczek M, Weber-Dąbrowska B, Międzybrodzki R, Letkiewicz S, Fortuna W, Rogóż P, Szufnarowski K, Jończyk-Matysiak E, Olchawa E, Walaszek KM, Górski A (2017) Antiphage activity of sera during phage therapy in relation to its outcome. Future Microbiol 12:109-117. https://doi. org/10.2217/fmb-2016-0156

Międzybrodzki R, Borysowski J, Weber-Dąbrowska B, Fortuna W, Letkiewicz S, Szufnarowski K, Pawełczyk Z, Rogóż P, Kłak M, Wojtasik E, Górski A (2012) Clinical aspects of phage therapy. Adv Virus Res 83:73-121. https://doi.org/10.1016/B978-0-12394438-2.00003-7

Ochs HD, Davis SD, Wedgwood RJ (1971) Immunologic responses to bacteriophage phi-X 174 in immunodeficiency diseases. J Clin Invest 50(12):2559-2568. https://doi.org/10.1172/JCI106756

Ooi ML, Drilling AJ, Morales S, Fong S, Moraitis S, Macias-Valle L, Vreugde S, Psaltis AJ, Wormald PJ (2019) Safety and tolerability of bacteriophage therapy for chronic rhinosinusitis due to Staphylococcus aureus. JAMA Otolaryngol Head Neck Surg 145(8):723-729. https://doi.org/10.1001/jamaoto.2019.1191

Safir MC, Bhavnani SM, Slover CM, Ambrose PG, Rubino CM (2020) Antibacterial drug development: a new approach is needed for the field to survive and thrive. Antibiotics 9(7):E412. https://doi.org/10. 3390/antibiotics 9070412

Ujmajuridze A, Chanishvili N, Goderdzishvili M, Leitner L, Mehnert U, Chkhotua A, Kessler TM, Sybesma W (2018) Adapted bacteriophages for treating urinary tract infections. Front Microbiol 9: 1832. https://doi.org/10.3389/fmicb.2018.01832

Publisher's note Springer Nature remains neutral with regard to jurisdictional claims in published maps and institutional affiliations. 